\title{
ANTI HYPERGLYCAEMIC AND ANTIOXIDANT ACTIVITY OF CATUNAREGAM SPINOSA (THUNB) AGAINST DEXAMETHASONE INDUCED DIABETES IN RATS
}

\author{
JYOTHI BASINI ${ }^{*}$, D. SWETHA ${ }^{1}$, G. MALLIKARJUNA ${ }^{1}$ \\ 1Department of Pharmacology, Seven Hills College of Pharmacy, Tirupati-517561, Andhra Pradesh, India \\ Email: jyothiphdcologyvmk@gmail.com
}

Received: 12 Feb 2019 Revised and Accepted: 23 Apr 2019

\begin{abstract}
Objective: The study was aimed at evaluating the folkloric use of the Catunaregam spinosa (Thunb) bark for its hypoglycaemic and antioxidant activity against dexamethasone-induced diabetes in wistar rats.

Methods: Diabetes was induced in wistar rats by dexamethasone administration $10 \mathrm{mg} / \mathrm{kg}$, b. wt., s. $c$ for 11 consecutive days to all group animals (except Group I). After confirmation of diabetes, the animals were divided into 5 groups $(\mathrm{n}=6)$. Group I: Vehicle control treated with normal saline only, Group II: Diabetic control treated with dexamethasone only, Group III: Standard control treated with dexamethasone plus glibenclamide (5 $\mathrm{mg} / \mathrm{kg}$, b. wt., $p . o$ ), Group IV and V: Test control received dexamethasone plus ethanolic extract of Catunaregam spinosa (EECS) at graded doses of $200 \mathrm{mg} / \mathrm{kg}$, b. wt. and $400 \mathrm{mg} / \mathrm{kg}$, b. wt., p. o for 21 days respectively. On the last day of the experiment, the effect of Catunaregam spinosa bark was measured by estimating the biochemical and antioxidant parameters.
\end{abstract}

Results: There was a significant alteration in the serum glucose, HbA1c, total proteins, serum lipid profile and tissue antioxidant parameters in dexamethasone-treated animals when compared to the normal control rats.

In test groups treated with glibenclamide and EECS, it was significantly ameliorated the altered parameters such as serum glucose, HbA1c, total proteins, serum lipid profile and the antioxidant parameters like SOD, CAT, GSH and MDA when compared to dexamethasone-treated animals with evidence of histopathological studies of the pancreas.

Conclusion: The results indicated that the ethanolic extract of Catunaregam Spinosa (Thunb) bark has shown the hypoglycemic and antioxidant property.

Keywords: Natural products, Catunaregam spinosa (Thunb), Hypoglycemic and Antioxidant activity, Dexamethasone

(C) 2019 The Authors. Published by Innovare Academic Sciences Pvt Ltd. This is an open access article under the CC BY license (http://creativecommons.org/licenses/by/4.0/) DOI: http://dx.doi.org/10.22159/ijpps.2019v11i6.32563

\section{INTRODUCTION}

Diabetes mellitus is a metabolic disorder characterized by an abnormality in carbohydrate, lipid and protein metabolism resulting in chronic hyperglycemia and abnormality of lipid profile. Chronic hyperglycemia of diabetes is associated with long term damage, dysfunction and eventually the failure of organs, especially the eyes, kidneys, nerves, heart and blood vessels [1]. Environmental factors such as diet, obesity, sedentary lifestyle and other factors like high family aggregation, insulin resistance, nutritional status, age increase the risk of diabetes [2]. Diabetes is managed with drugs such as metformin, sulfonylureas, thiazolidinedione's etc and as well as artificial insulin $[3,4]$. The serious adverse side effects like liver problems, lactic acidosis and diarrhoea [5, 6]. Diabetes is currently affecting around 143 million people [7], the number of those affected is increasing day by day by 2030 and it is predicted to reach 366 million populations worldwide [8]. Management of diabetes without any side effects is still a challenge for the medical system. This leads to an increasing search for improved anti-diabetic drugs [9]

Medicinal plants have been used in the Indian traditional system of medicine and have shown anti-diabetic activity $[10,11]$. The number of active constituents present in medicinal plants is thought to act on a variety of targets by different mechanisms. Catunaregam spinosa (Thunb) belongs to the family Rubiaceae is commonly known as Gedhpal or Emetic nut. This species is common as undergrowth in the sub-Himalayan tract [12]. The raw fruits have a highly astringent taste due to high tannin content. The seeds contain essential oil and organic acid. The dried and powdered fruit pulp is credited with emetic properties [13]. Plant bark is reported for diarrhoea, dysentery, abortifacient, antihelminthic and antipyretic [14]. It is also considered to be a sedative, hypoglycaemic and stomach ache as first aid remedy. Roots are used in the treatment of epilepsy, eye ache and urinary infection. The fruit is used as emetic and the leaves are used in pulmonary infections $[15,16]$. Catunaregam spinosa also used as carminative, antipyretic, cures abscess, ulcers, inflammations, wounds, tumours and skin diseases [17]. Based on the scientific evidence of the data, the research was carried out to evaluate the hypoglycaemic and antioxidant activity of ethanolic extract of Catunaregam spinosa (Thunb) (EECS) bark against dexamethasone-induced diabetes in wistar rats.

\section{MATERIALS AND METHODS}

Collection and authentication of plant specimen

The stem barks of Catunaregam spinosa (Thunb) were collected from surrounding areas of Seshachalam hills, Chittoor district and Andhra Pradesh (A. P). The plant material was authenticated by Dr. K. Madhava chetty, Professor, Department of Botany, Sri Venkateswara University, Tirupati, A. P, and India.

\section{Animals}

Healthy Adult Male Wistar rats weighing 150-200 gms were procured from Raghavendra enterprises, Bangalore and were maintained under standardized environmental conditions 12-h light/dark cycle, $24{ }^{\circ} \mathrm{C}$ and 35 to $60 \%$ humidity, provided free access to pellet diet and purified drinking water ad libtium. The experimental protocol was approved by Institutional Animal Ethical Committee of Krishna Teja Pharmacy College, Tirupati, A. P (Registered No. 1521/P0/11/CPCSEA-Committee for the purpose of control and supervision of experimental animals).

\section{Preparation of plant extract}

The plant barks were isolated, washed, shade dried and mechanically grinded to coarse powder. The powdered drug was 
subjected to continuous hot percolation with solvent $70 \%$ ethanol using soxhlet apparatus with 1:4 volumes. The extraction was carried out until the solvent becomes colourless and the solvent was removed from the extract by evaporation. The dried extract thus obtained was preserved in desicator [18]. The EECS was evaluated for phytochemical constituents using standard procedures $[19,20]$.

\section{Experimental design}

Experimental rats were taken and divided into five groups each containing six animals.

Group I animals served as vehicle control received $0.5 \mathrm{ml}$ of normal saline orally.

Group II animals served as diabetic control received dexamethasone (10 mg/kg, b. wt., s. c) for 11 consecutive days [21].

Group III animals served as standard control received dexamethasone $(10 \mathrm{mg} / \mathrm{kg}$, b. wt., s. c) for 11 days and glibenclamide (5 mg/kg, b. wt., p.o) for $21 \mathrm{~d}$.

Group IV and $\mathbf{V}$ animals served as test control received dexamethasone $(10 \mathrm{mg} / \mathrm{kg}$, b. wt., s. c) for $11 \mathrm{~d}$ and EECS at graded doses of $200 \mathrm{mg} / \mathrm{kg}, \mathrm{b}$. wt, and $400 \mathrm{mg} / \mathrm{kg}$, b. wt., $p$. $o$ for 21 days respectively.

\section{Assessment of the hypoglycemic effect}

The blood samples were collected through retro-orbital route from each rat under mild ether anesthesia on $22^{\text {nd }}$ day and serum was separated by centrifugation of blood at $4000 \mathrm{rpm}$ for $10 \mathrm{~min}$. The serum was used for the estimation biochemical parameters such as Glycosylated haemoglobin $\left(\mathrm{HbA}_{1} \mathrm{c}\right)$, serum glucose levels, Total cholesterol (TC), Triglycerides (TGL), High density lipoprotein (HDL), Low density lipoprotein (LDL), Very low density lipoprotein (VLDL) [22-26] and total protein (TP) [27]. From each group, one animal were taken and sacrificed for pancreas isolation and same one part is used for estimation of antioxidant parameters like
Superoxide dismutase (SOD), Catalase (CAT), Glutathione reductase (GSH) and Malondialdehyde (MDA) [28-31] and another part processed for Histopathological studies [32].

\section{Statistical analysis}

The results were expressed as mean \pm SEM/SD differences in groups for biochemical estimations. Statistical analysis was determined by one way-analysis of variance (ANOVA), individual groups were compared using Dunnett's t-test. $P$ value $<0.05$ has been considered as a statistical significance level.

\section{RESULTS}

Preliminary phytochemical screening of EECS revealed the presence of Carbohydrates, Glycosides, Saponins, Terpenoids, Phenols, Tannins, Flavonoids, Proteins, Amino acids and Phytosterols.

\section{Acute toxicity studies and test dose selection}

The acute toxicity studies were conducted as per OECD (Organization for economic co-operation and development) 423 guidelines (Acute Toxic Class Method). No sign of toxicity and mortality was observed up to the maximum dose administered a dose of $2000 \mathrm{mg} / \mathrm{kg}$, b. wt. $p$. $o$ of EECS. The dose was selected based on the maximum dose administered with $1 / 10^{\text {th }}$ and $1 / 20^{\text {th }}$ as low dose and a high dose of test extract.

\section{Effect of EECS on $\mathrm{HbA}_{1} \mathrm{c}$ and serum total protein}

Table 1 represents a significant $(P<0.001)$ increased in the level of glycosylated haemoglobin (HbA1c) and decreased in the serum total protein levels upon administration of dexamethasone as compared to the vehicle-treated animals. Upon treatment with standard drug glibenclamide $(5 \mathrm{mg} / \mathrm{kg}, \mathrm{b}$. wt., p. o) and EECS at both dose levels ( $200 \mathrm{mg} / \mathrm{kg}$, b. wt., and $400 \mathrm{mg} / \mathrm{kg}$, b. wt., $p$. o) for $21 \mathrm{~d}$ showed a significant $(P<0.05) \quad(P<0.01)$ restoration of the abnormal levels compared to the diabetic control rats.

Table 1: Effect of EECS on $\mathrm{HbA}_{1} \mathrm{c}$ and serum total protein in dexamethasone-induced diabetic rats

\begin{tabular}{lll}
\hline Groups & Glycosylated Haemoglobin-HbA1c (\%) & Total protein (mg/dl) \\
\hline Vehicle control & $5.22 \pm 0.661$ & $6.780 \pm 0.947$ \\
Diabetic control & $8.58 \pm 0.568$ & $4.600 \pm 0.687$ \\
Standard control & $5.14 \pm 0.683^{* * *}$ & $6.260 \pm 0.598^{* * *}$ \\
EECS-I $(200 \mathrm{mg} / \mathrm{kg}$, b. wt.) & $5.88 \pm 0.624^{* *}$ & $4.924 \pm 0.778^{*}$ \\
EECS-II $(400 \mathrm{mg} / \mathrm{kg}$, b. wt.) & $5.70 \pm 0.870^{* * *}$ & $5.960 \pm 0.969^{* * *}$ \\
\hline
\end{tabular}

Values were expressed as mean \pm SEM $(\mathrm{n}=6) .{ }^{*} P<0.05,{ }^{* *} P<0.01,{ }^{* * *} P<0.001$. As compared with diabetic control (One-way ANOVA followed by Dunnett's test).

\section{Effect of EECS on serum glucose levels}

Table 2 shows dexamethasone administration raised the serum glucose levels significantly $(P<0.001)$ on day $4,7,10,15$ and 21 leading to hyperglycemia when compared to the vehicle control animals. Reversal of raise in serum glucose level was found in the animals treated with standard drug glibenclamide $(5 \mathrm{mg} / \mathrm{kg}$, b. wt., p. o) and EECS at both dose levels $(200 \mathrm{mg} / \mathrm{kg}$, b. wt., and 400 $\mathrm{mg} / \mathrm{kg}$, b. wt., p. o) for $21 \mathrm{~d}$ when compared to the diabetic control rats.

Table 2: Effect of EECS on serum glucose levels in dexamethasone-induced diabetic rats

\begin{tabular}{|c|c|c|c|c|c|}
\hline \multirow[t]{2}{*}{ Groups } & \multicolumn{5}{|c|}{ Serum Glucose Levels (mg/dl) } \\
\hline & $4^{\text {th }}$ day & $7^{\text {th }}$ day & $10^{\text {th }}$ day & $15^{\text {th }}$ day & $21^{\text {st }}$ day \\
\hline Vehicle control & $85.0 \pm 3.536$ & $88.0 \pm 2.550$ & $89.2 \pm 1.772$ & $91.0 \pm 2.646$ & $97.33 \pm 1.333$ \\
\hline Diabetic control & $159.2 \pm 2.933$ & $197.4 \pm 2.098$ & $210.0 \pm 2.450$ & $217.0 \pm 1.453$ & $219.67 \pm 2.881$ \\
\hline Standard control & $103.4 \pm 1.715^{* * *}$ & $99.80 \pm 1.020^{* * *}$ & $94.80 \pm 1.655^{* * *}$ & $92.67 \pm 1.333^{* * *}$ & $88.67 \pm 2.881^{* * *}$ \\
\hline EECS-I (200 mg/kg, b. wt.) & $127.6 \pm 1.806^{* *}$ & $121.0 \pm 1.049^{* *}$ & $110.4 \pm 1.678^{* *}$ & $108.3 \pm 1.332^{* *}$ & $105.67 \pm 1.373^{* *}$ \\
\hline EECS-II (400 mg/kg, b. wt.) & $110.4 \pm 1.852^{* * *}$ & $105.4 \pm 2.821^{* * *}$ & $103.8 \pm 3.513^{* * *}$ & $97.00 \pm 1.577^{* * *}$ & $94.00 \pm 1.577^{* * *}$ \\
\hline
\end{tabular}

Values were expressed as mean \pm SEM $(\mathrm{n}=6) .{ }^{*} P<0.05,{ }^{* *} P<0.01,{ }^{* *} P<0.001$. As compared with diabetic control (One-way ANOVA followed by Dunnett's test)

\section{Effect of EECS on serum lipid profile}

Table 3 demonstrates that dexamethasone for 11 consecutive days causes an imbalance in lipid metabolism provokes hyperlipidemic condition in rats with significant $(P<0.001)$ elevation of TC, TGL, LDL,
VLDL and decrease in the HDL levels when compared to the vehicle control rats. Treatment with standard drug glibenclamide $(5 \mathrm{mg} / \mathrm{kg}, \mathrm{b}$. wt., p. o) and EECS at both dose levels $(200 \mathrm{mg} / \mathrm{kg}$, b. wt., and $400 \mathrm{mg} / \mathrm{kg}$, b. wt., $p . o)$ for $21 \mathrm{~d}$ showed a significant $(P<0.05)(P<0.01)$ amelioration of abnormal lipid profile when compared to the diabetic control rats. 
Table 3: Effect of EECS on serum lipid profile in dexamethasone-induced diabetic rats

\begin{tabular}{|c|c|c|c|c|c|}
\hline \multirow[t]{2}{*}{ Groups } & \multicolumn{5}{|c|}{ Serum lipid profile (mg/dl) } \\
\hline & Total cholesterol & Triglycerides & HDL & LDL & VLDL \\
\hline Vehicle control & $181.8 \pm 5.936$ & $146.2 \pm 2.663$ & $44.0 \pm 1.703$ & $41.00 \pm 1.316$ & $11.60 \pm 1.509$ \\
\hline Diabetic control & $265.8 \pm 10.220$ & $177.2 \pm 2.728$ & $23.6 \pm 1.80$ & $93.20 \pm 3.374$ & $33.60 \pm 1.034$ \\
\hline Standard control & $190.8 \pm 3.338^{* * *}$ & $148.6 \pm 2.064^{* * *}$ & $42.2 \pm 2.969^{* * *}$ & $52.80 \pm 2.374^{* * *}$ & $12.60 \pm 0.924^{* * *}$ \\
\hline EECS-I (200 mg/kg, b. wt.) & $213.0 \pm 4.447^{*}$ & $161.0 \pm 3.894^{*}$ & $37.2 \pm 2.489^{*}$ & $67.00 \pm 2.447^{* *}$ & $19.20 \pm 0.884^{* *}$ \\
\hline EECS-II (400 mg $/ \mathrm{kg}, \mathrm{b} . \mathrm{wt}$.) & $195.4 \pm 3.749^{* * *}$ & $154.0 \pm 2.140^{* * *}$ & $40.0 \pm 2.316^{* *}$ & $57.20 \pm 2.374^{* * *}$ & $14.80 \pm 0.374^{* * *}$ \\
\hline
\end{tabular}

Values were expressed as mean $\pm \operatorname{SEM}(\mathrm{n}=6) .{ }^{*} P<0.05,{ }^{* *} P<0.01,{ }^{* * *} P<0.001$. As compared with diabetic control (One-way ANOVA followed by Dunnett's test)

\section{Effect of EECS on tissue pro-oxidant and anti-oxidants}

Table 4 demonstrates that dexamethasone induction caused significant $(P<0.001)$ decrease in the antioxidant enzymes like SOD, CAT, GSH and increase in the LPO levels indicating that production of reactive oxygen species leading to free radical damage when compared to the vehicle control rats. Treatment with standard drug glibenclamide ( $5 \mathrm{mg} / \mathrm{kg}$, b. wt., p. o) and EECS at both dose levels ( $200 \mathrm{mg} / \mathrm{kg}$, b. wt., and $400 \mathrm{mg} / \mathrm{kg}$, b. wt., p. o) for $21 \mathrm{~d}$ showed a significant $(P<0.05) \quad(P<0.01)$ reversal of abnormal pro-oxidant and antioxidant enzymes when compared to the diabetic control rats.

Table 4: Effect of EECS on tissue pro-oxidant and anti-oxidants in dexamethasone-induced diabetic rats

\begin{tabular}{|c|c|c|c|c|}
\hline Groups & $\begin{array}{l}\text { SOD } \\
(\mu / \mathrm{mg} \text { protein })\end{array}$ & $\begin{array}{l}\text { Catalase } \\
\left(\mu \mathrm{M} \mathrm{H}_{2} \mathrm{O}_{2} \text { consumed/mg protein }\right)\end{array}$ & $\begin{array}{l}\text { GSH } \\
\text { ( } \mu \text { g of GSH/mg protein) }\end{array}$ & $\begin{array}{l}\text { LPO } \\
\text { (nM of MDA/mg protein) }\end{array}$ \\
\hline Vehicle control & $18.20 \pm 1.583$ & $32.00 \pm 0.816$ & $29.40 \pm 0.509$ & $45.80 \pm 2.374$ \\
\hline Diabetic control & $8.680 \pm 1.080$ & $22.80 \pm 0.874$ & $12.40 \pm 0.509$ & $91.60 \pm 2.509$ \\
\hline Standard control & $16.00 \pm 1.316^{* * *}$ & $31.00 \pm 0.812^{* * *}$ & $27.80 \pm 0.633^{* * *}$ & $49.40 \pm 1.28^{* * *}$ \\
\hline EECS-I (200 mg/kg, b. wt.) & $13.40 \pm 1.509^{*}$ & $28.80 \pm 0.972^{*}$ & $24.60 \pm 0.599^{* *}$ & $65.00 \pm 2.362^{* *}$ \\
\hline EECS-II (400 mg/kg, b. wt.) & $15.00 \pm 1.312^{* *}$ & $30.40 \pm 0.949^{* *}$ & $26.60 \pm 0.897^{* * *}$ & $54.00 \pm 1.312^{* * *}$ \\
\hline
\end{tabular}

Values were expressed as mean \pm SEM $(\mathrm{n}=6) .{ }^{*} P<0.05,{ }^{* *} P<0.01,{ }^{* * *} P<0.001$ as compared with diabetic control (One-way ANOVA followed by Dunnett's test)

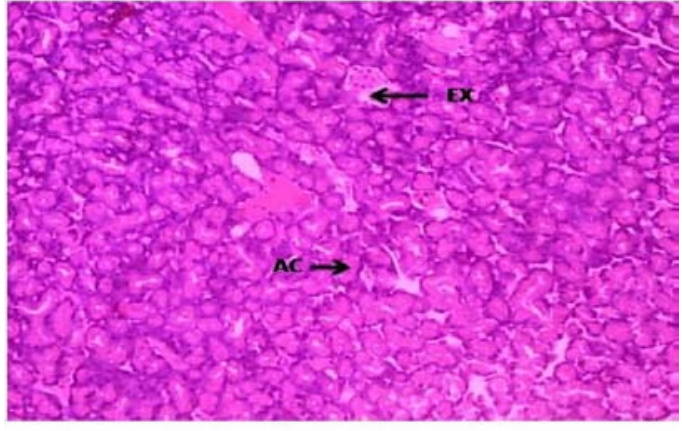

NORMAL PANGREAS 10X

Fig. 1: Normal control (Group I)-Received normal saline has shown the normal architecture of pancreatic tissue with islet of langerhans and acinar cells. (Abbreviation: EX-Exocrine, AC-Acinar)

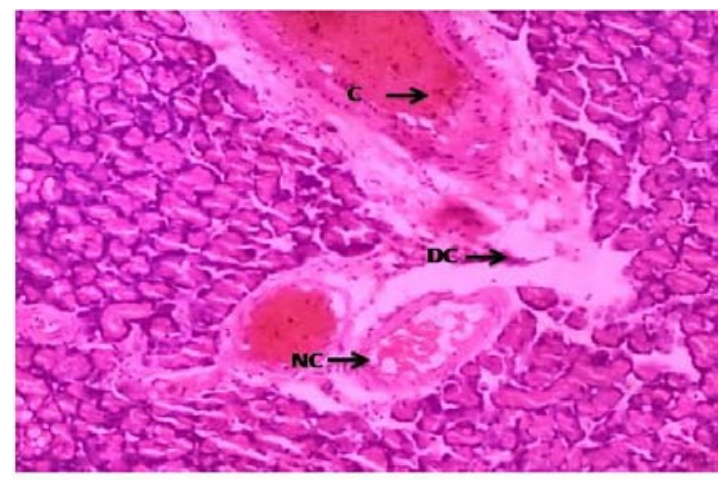

\section{CONTROL PANCREAS 10X}

Fig. 2: Diabetic control (Group II)-Treated with dexamethasone $10 \mathrm{mg} / \mathrm{kg} s . c$. observed congestion, degenerative changes and necrotic changes in pancreatic cells indicate structural damage of pancreas. (Abbreviation: C-Congestion, DC-Degenerative changes, NC-Necrotic changes)

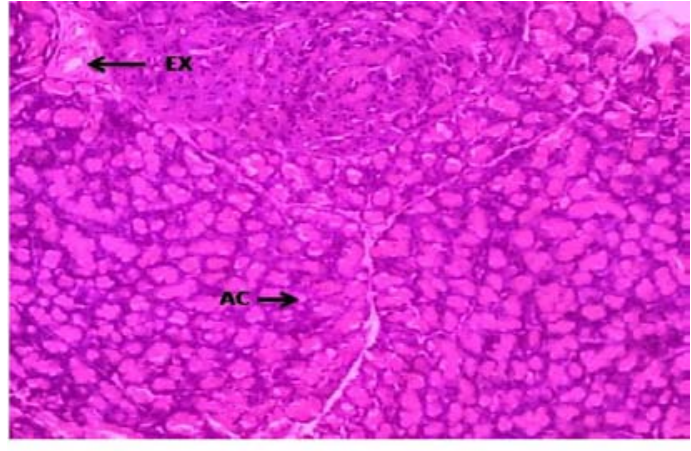

STANDARD PANCREAS 10X

Fig. 3: Standard group III-treated with dexamethasone (10 $\mathrm{mg} / \mathrm{kg}, s . c)$ and glibenclamide $(5 \mathrm{mg} / \mathrm{kg}$, p. o.)-the regeneration of pancreatic tissue shows similar to normal cytoarchitecture. (Abbreviation: EX-Exocrine, AC-Acinar)

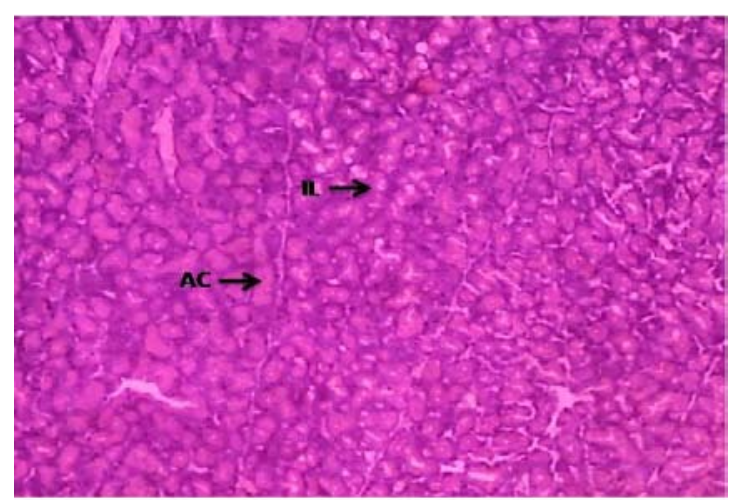

TEST-1 PANCREAS 10X

Fig. 4: Test 1 (EECS $200 \mathrm{mg} / \mathrm{kg}$ )-The regeneration of pancreatic tissue takes place and shows similar to normal cytoarchitecture. (Abbreviation: AC-Acinar, IL-Islets of langerhans) 


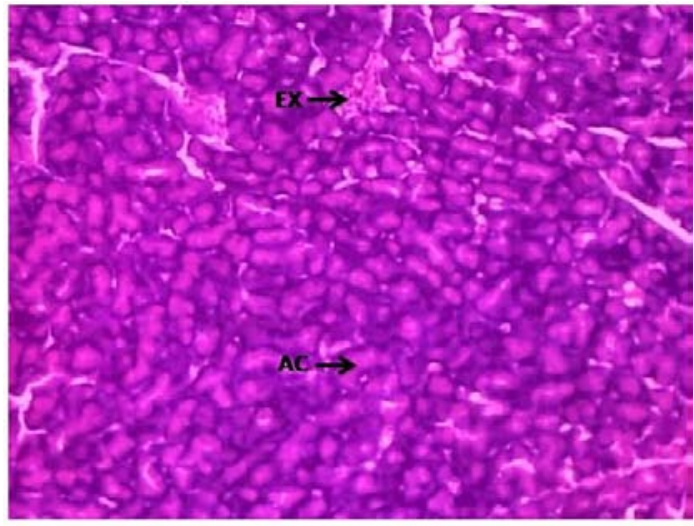

TEST-2 PANCREAS 10X

Fig. 5: Test 2 (EECS $400 \mathrm{mg} / \mathrm{kg}$ )-regenerative changes take place in pancreatic tissue and show similar to normal cytoarchitecture. (Abbreviation: EX-Exocrine, AC-Acinar)

\section{Histopathological studies}

Dexamethasone administration for $21 \mathrm{~d}$ revealed that the pancreas with degeneration of pancreatic cells and inflammation vacuoles may be due to the free radical damage compared to the normal vehicle control with normal parenchymatous cell without any degeneration and inflammation. Treatment with glibenclamide and EECS significantly reduced the marked inflammation and degeneration of pancreas as compared to the diabetic control rats.

\section{DISCUSSION}

In the present study Catunaregam spinosa (Thunb) was selected for hypoglycaemic and antioxidant activity evaluation owing to its ethnomedicinal use in curing diabetes. Therefore, the study was undertaken to justify its claimed use. Ethanolic extract of Catunaregam spinosa (Thunb) (EECS) bark was prepared by soxhlet method and stored in the refrigerator at $4{ }^{\circ} \mathrm{C}$. Rats were selected as experimental animals for evaluating anti-hyperglycemic and antioxidant activity. Acute toxicity was conducted as per OECD guidelines and the EECS was not showed any toxicity at the dose of $2000 \mathrm{mg} / \mathrm{kg}$ and no death was reported for $72 \mathrm{~h}$. Preliminary phytochemical screening of EECS revealed the presence of Carbohydrates, Glycosides, Saponins, Terpenoids, Phenols, Tannins, Flavonoids, Proteins, Amino acids and Phytosterols.

Subcutaneously administration of dexamethasone for $11 \mathrm{~d}$ causes significant $(P<0.001)$ elevation of HbA1c and decrease in the serum total protein levels in diabetic control rats as compared to the vehicle control. Glucocorticoids are widely used therapeutic tools particularly in treatment for anti-inflammatory and immunemodulatory purposes. Side effects of glucocorticoid treatment include steroid diabetes [33, 34]. It induces hyperglycemia is partially due to increased hepatic glucose production and insulin resistance of peripheral tissues. Moreover, glucocorticoids are known to inhibit insulin secretion [35, 36]. The underlying mechanism involves increased $\alpha 2$-adrenoceptor signaling [37], increased Kv channel activity [38] and impaired glucose metabolism $[39,40]$. They diminish glucose utilization in the peripheral tissues cause an increase in protein breakdown by increasing the synthesis of glutamine and lipolysis, thereby providing amino acids and glycerol for gluconeogenesis [41]. HbA1c as a biomarker for monitoring the levels of glucose among type 2 diabetic patients provides a reliable measure of chronic glycaemia and correlates well with the risk of long-term diabetes complications. So that it is currently considered the test of choice for monitoring and chronic management of diabetes [42]. During diabetes, the excess of glucose present in the blood reacts with hemoglobin to form glycosylated haemoglobin [43]. The rate of glycation is proportional to the concentration of blood glucose [44, 45]. Treatment with glibenclamide and EECS $200 \mathrm{mg} / \mathrm{kg}$ and $400 \mathrm{mg} / \mathrm{kg} \mathrm{b}$. wt, p.o. ameliorated the abnormal levels of HbA1c and TP when compared to the diabetic control rats depicted in table 1.

In the present study, it has been found that the elevation of serum glucose and abnormal changes in the lipid profile in dexamethasonetreated rats indicating that the hyperglycemia and Hyperlipidemia $[46,47]$. Dexamethasone increases in glucose levels leading to hyperglycemia due to the inhibition of GLUT-4 (glucose transporter) translocation from intracellular compartments to the plasma membrane particularly of skeletal muscles $[48,49]$. The elevation of serum glucose levels in diabetic control rats were significantly restored upon treatment with the standard glibenclamide and ethanolic extract of Catunaregam spinosa (Thunb) at both dose levels $(200 \mathrm{mg} / \mathrm{kg}$, b. wt., and $400 \mathrm{mg} / \mathrm{kg}$, b. wt., p. o.) for $21 \mathrm{~d}$ as compared to the vehicle control rats which was depicted in table 2 . The possible mechanism by which EECS mediated its antihyperglycemic effect could be by the potentiation of pancreatic secretion of insulin from existing $\beta$-cells of islets thereby increase glucose utilization from tissues through GLUT-4.

Pharmacological doses of glucocorticoids induce $o b$ gene expression in rat adipocyte tissues within $24 \mathrm{~h}$ which is followed by complex metabolic changes like hyperleptinemia, resulting in decreased in food consumption, with enhanced blood glucose and an imbalance in lipid metabolism leading to Hyperlipidemia [50-51]. On administration of dexamethasone, significantly $(P<0.001)$ elevate the serum lipid parameters such as TC, TGL, LDL, VLDL and decrease in the HDL levels when compared to the vehicle control rats. Treatment with EECS ( $200 \mathrm{mg} / \mathrm{kg}$, b. wt., and $400 \mathrm{mg} / \mathrm{kg}$, b. wt., p. o.) for $21 \mathrm{~d}$ had ameliorated the abnormal lipid profile depicted in table 3 . From the results of the present study, it may be suggesting that improvement in food intake and HDL levels and also a reduction in blood glucose. And it confirms that EECS shows protection of vital organs like pancreas, liver, heart, spleen and kidney thereby reducing the causation of diabetes [52].

The antioxidant enzymes such as catalase (CAT), glutathione $S$ transferase (GST), glutathione peroxidase (GPx) are able to resist oxidative stress by scavenging free radicals, inhibiting lipid peroxidation, increasing glutathione and catalase activity [53]. Oxidative stress can be generated by hyperglycemia and for a long time, it has been accused to cause insulin resistance. Insulin resistance induces the release of cytokines like TNF-alpha, IL-8 which leads to the development of oxidative stress in the liver by reducing the mitochondrial levels of $\mathrm{Cu} / \mathrm{Zn}$ SOD, glutathione, producing $\mathrm{H} 2 \mathrm{O} 2$ radicals and leads to increase in lipid peroxidation [54]. On Administration of dexamethasone induces the reduction of antioxidant enzymes such as SOD, CAT, GSH and increase in the lipid peroxidation when compared to the vehicle control animals. EECS (200 mg/ $\mathrm{kg}$ and $400 \mathrm{mg} / \mathrm{kg}$ ) was given orally for $21 \mathrm{~d}$ in both doses increases the reduced levels of SOD, CAT and GSH thus protecting the tissues from oxidative stress by inhibit free radical generation and reduce insulin resistance.

Lipid peroxidation is usually measured through its catabolite malondialdehyde (MDA) as a marker of oxidative stress [55, 56]. A marked increase in the concentration of MDA in dexamethasoneinduced diabetic rats indicated that enhances lipid peroxidation leading to tissue injury and failure of the antioxidant defense mechanism to prevent the formation of excess free radicals. EECS showed the ability to prevent increased MDA levels in group 4 and 5 animals, suggesting that EECS inhibited lipid peroxidation and improved the pathological condition of diabetes. Hence, the possible antioxidant potential of the EECS may be due to the presence of polyphenolic compounds i.e. flavonoids and phytosterols.

EECS significantly reduced the marked inflammation and degeneration of pancreas as compared to the diabetic control rats. While dexamethasone administration revealed that the pancreas with degeneration of pancreatic cells and inflammation vacuoles may be due to the free radical damage compared to the normal vehicle control with normal parenchymatous cell without any degeneration and inflammation. 


\section{CONCLUSION}

Medicinal plants have continued to be a powerful source for new drugs contributing about $90 \%$ of the newly discovered pharmaceuticals. As for the developed countries, the use of herbal medicine for chronic diseases is encouraged because there is concern about the adverse effects of chemical drugs and treatment using medicines of natural origin appears to offer more gentle means of managing such diseases. Herbal drugs are prescribed widely because of their effectiveness, fewer side effects and are relatively low in cost. The above data suggest that the ethanolic extract of Catunaregam spinosa (Thunb) bark possess hypoglycaemic and antioxidant activity in dexamethasone-treated rats as evidenced by the restoration of the abnormal parameter levels. This may be due to the presence of bioactive constituents in the plant such as tannins, flavonoids, saponins, polyphenols etc. Further studies are required to isolate the active principle responsible for hypoglycaemic and antioxidant activity.

\section{ACKNOWLEDGMENT}

Authors are thankful to the Department of Microbiology, Sri Venkateswara University, Tirupati, India, for providing analytical support in their laboratory to complete our research work.

\section{ABBREVIATIONS}

A. P: Andhra Pradesh, CPCSEA: Committee for the purpose of control and supervision of experimental animals, ANOVA: Analysis of variance, LPO: Lipid peroxidation, OECD: Organization for economic co-operation and development, TP: Total protein, HbA1c: Glycosylated haemoglobin, GLUT-4: Glucose transporter 4, VLDL: Very low density lipoproteins, LDL: Low density lipoproteins, TGL: Triglycerides, TC: Total cholesterol, HDL: High Density Lipoproteins, $\mathrm{Cu} / \mathrm{Zu}$ : Copper/Zinc, GST: Glutathione-S-transferase, GPx: Glutathione peroxidise, TNF- $\alpha$ : Tumour necrosis factor- $\alpha$, IL-8: Interleukins-8, $\mathrm{H}_{2} \mathrm{O}_{2}$ : Hydrogen peroxidise, SOD: Superoxide dismutase, CAT: Catalase, GSH: Reduced Glutathione, MDA: Malondialdehyde, EECS: Ethanolic extract of Catunaregam spinosa, AC: Acinar cells, EX: Exocrine, IL: Islets of langerhans, NC: Necrotic changes, DC: Degenerative changes, C: Congestion

\section{AUTHORS CONTRIBUTIONS}

All the author have contributed equally

\section{CONFLICT OF INTERESTS}

The authors declare that there is no conflict of interest

\section{REFERENCES}

1. Huang THW, Peng G, Kota BP, Li GQ, Yamahara J, Roufogalis BD. Anti-diabetic action of Punica granatum flower extract: activation of PPAR-C and Identification of an active component. Toxicol Appl Pharmacol 2005;207:160-9.

2. Deepashree BN, Prakash JA. Study on the nutritional status of diabetics and associated risk factors. J Human Ecol 2007;21:269-74.

3. Fowler MJ. Diabetes treatment, part 2: oral agents for glycemic management. Clin Diabetes 2007;25:1733-42.

4. Markussen J. New insulins: types and actions. In: Turtle JR, Kaneko T, Osato S. editors. Diabetes in the new millenium. Sydney: the endocrinology and diabetes research foundation of the university of sydney; 1999. p. 251-64.

5. Rajalakshmi M, Eliza J, Priya CE, Nirmala A, Daisy P. Antidiabetic properties of Tinospora cordifolia stem extracts on streptozotocin-induced diabetic rats. Afr J Pharm Pharmacol 2009;3:171-80.

6. Fowler MJ. Diabetes treatment, part 2: oral agents for glycemic management. Clin Diabetes 2007;25:131-4.

7. Mentreddy SR, Mohamed AI, Rimando AM. Medicinal plants with hypoglycemic/anti-hyperglycemic properties: a review. Proc Assoc Adv Ind Crop Conf 2005;20:341-53.

8. Ponnusamy S, Ravindran R, Zinjarde S, Bhargava S, Kumar AR. Evaluation of traditional Indian antidiabetic medicinal plants for human pancreatic amylase inhibitory effect in vitro. Evid
Based Complementary Altern Med 2011;1-10. Doi:10.1155/2011/515647

9. Raju N Patil, Ravindra Y Patil, Bharati Ahirwar, Dheeraj Ahirwar. Evaluation of antidiabetic and related actions of some Indian medicinal plants in diabetic rats. Asian Pac J Trop Med 2011;4:20-3.

10. Dineshkumar B, Mitra A, Manjunatha M. In vitro and in vivo studies of antidiabetic Indian medicinal plants: a review. J Herbal Med Toxicol 2009;3:9-14.

11. Grover JK, Yadav S, Vats V. Medicinal plants of India with antidiabetic potential. J Ethnopharmacol 2002;81:81-100.

12. $\mathrm{R}$ Senthamarai, $\mathrm{T}$ Shri Vijaya Kirubha, $\mathrm{S}$ Gayathri. Pharmacognostical and phytochemical studies on fruits of Catunaregam spinosa linn. J Chem Pharm Res 2011;3:829-38.

13. The World health report, life in the $21^{\text {st }}$ century: a vision for all. World Health Organization Geneva; 1998.

14. Sharma PC, Yelne MB, Denis JJ. Database on Medicinal plants used in Ayurveda 2000;2:380-3.

15. Warrier PK, Ramankutty C, Nair RV. Indian medicinal plant-a compendium of 500 species. Orient Longman 1999;3:32-6.

16. Agrawal SS, Singh VK. Immunomodulatory-a review of studies on Indian medicinal plants and synthetic peptides, part-1, medicinal plants. Proc Indian Natl Sci Acad 1999;62:179-204.

17. Kokate CK, Purohit AP, Gokhale SB. Textbook of pharmacognosy. $6^{\text {th }}$ ed. Nirali publication, Pune, India; 1977. p. 23-4.

18. Kokate CK, Purohit AP, Gokhale SB. Pharmacognosy. 24th ed. Nirali Prakakashan; 2003. p. 149-53.

19. Khandelwal KR. Practical pharmacognosy techniques and experiments. $2^{\text {nd }}$ ed. Pune: Nirali Prakashan; 2000. p. 149-56.

20. Shalam MD, Harish MS, Farhana SA. Prevention of dexamethasone and fructose-induced insulin resistance in rats by SH-01D, a herbal preparation. Indian J Pharmacol 2006;38:419-22.

21. Eross J, Kreutzman D, Jimenez M, Keen R, Rogers S, Cowell C, et al. Colorimetric measurement of glycosylated protein in whole blood cells plasma and dried blood. Ann Clin Biochem 1984;21:519-22.

22. Jamkhande PG, Patil PH, Surana SJ. Evaluation of N-Butanolic fractions of Butea monosperma flowers on dexamethasoneinduced hyperglycemia and hyperlipidemia in mice. Int J Phytopharma Res 2010;1:5-10.

23. Shalam MD, Harish MS, Farhana SA. Prevention of dexamethasone and fructose-induced insulin resistance in rats by SH-01D, a herbal preparation. Indian J Pharmacol 2006;38:419-22.

24. Kaushal P, Subhash Chandra P, Japan P, Brijesh P, Mandev BP Effect of bitter gourd (Momordica charantia) fruit juice on glucose tolerance and lipid profile in type-II diabetic rats. Int J Drug Dev Res 2011;3:139-46.

25. Koyaguru N, Kumar VH, Jamadar MG, Huligol SV, Nayak N, Yendigeri SM. Antidiabetic and hepatoprotective activities of Tamarindus indica fruit pulp in alloxan-induced diabetic rats. Int J Pharmacol Clin Sci 2013;2:33-40.

26. Sarath Babu K, Nagendra Nayak, Hebbal GV. Hypoglycemic effect of alcohol extract of Eugenia jambolana seed against dexamethasone-induced diabetes in rats. Int J Med Health Sci 2015;4:77-81.

27. Lowry $\mathrm{OH}$, Rosebrough NJ, Farr AL, Randall RI. Protein measurement with the folin-phenol reagent. J Biol Chem 1951;193:265-72.

28. Kakkar P, Das B, Viswanathan PN. A modified spectroscopic assay of superoxide dismutase. Indian J Med Res 1984;21:13032.

29. Sinha AK. Colorimetric assay of catalase. Anal Biochem 1972;47:389-94.

30. Habig WH, Pabst MJ, Jakpoby WB. Glutathione transferase, a first enzymatic step in mercapturic acid formation. J Biol Chem 1974;249:7130-9.

31. Fraga CG, Leibouitz BE, Toppel AL. Lipid peroxidation measured as TBARS in tissue slices: characterization and comparison with homogenates and microsomes. Free Radical Biol Med 1988;4:155-61. 
32. Jelodar GA, Maleki M, Motadayen MH, Sirus S. Effect of fenugreek, onion and garlic on blood glucose and histopathology of the pancreas. Indian J Med Sci 2005;59:64-9.

33. Hoogwerf B, Danese RD. Drug selection and the management of corticosteroid-related diabetes mellitus. Rheum Dis Clin North Am 1999;25:489-505.

34. Schacke H, Docke WD, Asadullah K. Mechanisms involved in the side effects of glucocorticoids. Pharmacol Ther 2002;96:23-43.

35. Lambillotte C, Gilon P, Henquin JC. Direct glucocorticoid inhibition of insulin secretion: an in-vitro study of dexamethasone effects in mouse islets. J Clin Invest 1997; 99:414-23.

36. Jeong IK, Oh SH, Kim BJ, Chung JH, Min YK, Lee MS, et al. The effects of dexamethasone on insulin release and biosynthesis are dependent on the dose and duration of treatment. Diabetes Res Clin Pract 2001;51:163-71.

37. Hamamdzic D, Duzic E, Sherlock JD, Lanier SM. Regulation of $\beta 2$-adrenergic receptor expression and signaling in pancreatic $\beta$-cells. Am J Physiol 1995;269:E162-71.

38. Ullrich S, Berchtold S, Ranta F, Seebohm G, Henke G, Lupescu A et al. Serum and glucocorticoid-inducible kinase 1 (SGK1) mediates glucocorticoid-induced inhibition of insulin secretion. Diabetes 2005;54:1090-9.

39. Gremlich S, Roduit R, Thorens B. Dexamethasone induces posttranslational degradation of GLUT2 and inhibition of insulin secretion in isolated pancreatic $\beta$-cells: comparison with the effects of fatty acids. J Biol Chem 1997;272:3216-2.

40. Ling ZC, Khan A, Delauny F, Davani B, Ostenson CG, Gustafsson $\mathrm{JA}$, et al. Increased glucocorticoid sensitivity in islet $\beta$-cells: effects on glucose 6 phosphatase, glucose cycling and insulin release. Diabetologia 1998;41:634-9.

41. Bernard P, Schimmer, Keith LP. Adrenocorticotropic hormone; adrenocortical steroids and their synthetic analogues, inhibitors of the synthesis and actions of adrenocortical hormones. In: Brunton LL, Lazo JS, Parker KL. Goodman and Gillman's, The Pharmacological Basis of Therapeutics. USA: Mc Graw Hill; 2006. p. 1597-8.

42. Shariq I Sherwani, Haseeb A Khan, Aishah Ekhzaimy, Afshan Masood, Meena K Sakharkar. Significance of HbA1c test in diagnosis and prognosis of diabetic patients. Biomarker Insights 2016;11:95-104.

43. Alyassin D, Ibrahim KA. Minor hemoglobin fraction and level of fasting blood glucose. J Fac Med Unive Baghdad 1981; 23:373-80.
44. Ragini N, Prasad KVSRG, Bharathi K. Antidiabetic and antioxidant activity of shorea tumbuggnia rox. Int J Innovation Pharm Res 2011;2:113-21.

45. Arockia Jenecius, Alphonse A, Mohan VR, Doss A. Antidiabetic activity of bacolepis nervosa (wight and arn.) decne. ex moq extract on alloxan-induced diabetic rats. Int J Pharm Pharm Sci 2016;8:11.

46. Nanjan MJ. Serum glucose and triglyceride activity of some novel glitazones against dexamethasone-induced hyperlipidemia and insulin resistance. Indian J Pharmacol 2007;39:299-302.

47. Shalam M. Prevention of dexamethasone and fructose-induced insulin resistance in rats by $\mathrm{SH}-01 \mathrm{D}$, a herbal preparation. Indian J Pharmacol 2006;38:419-22.

48. Mahendran P, Devi CS. Effect of Garcinia cambogia extracts on lipids and lipoproteins compositions in dexamethasone administered rats. Indian J Physiol Pharmacol 2001;45:345-50.

49. Bruder ED. Metabolic consequences of hypoxia from birth and dexamethasone treatment in the neonatal rat: comprehensive hepatic lipid and fatty acid profiling. Endocrinology 2004;145:5364-72.

50. Wiesenberg I. Specific activation of the nuclear receptor PPAR and RORA by the anti-diabetic thiazolidinedione BRL 49653 and the anti-arthiritic thiazolidinedione derivative GGP 52608. Mol Pharmacol 1998;53:1131-6.

51. Kim DS, Kim TW, Park IK, Kang JS, Om AS. Effect of chromium picolinate supplementation on insulin sensitivity, serum lipid, and body weight in dexamethasone-treated rats. Metabolism 2002;51:589-94.

52. Shalam MD, Harish MS, Farhana SA. Prevention of dexamethasone and fructose-induced insulin resistance in rats by SH-01D, a herbal preparation. Indian J Pharmacol 2006;38:419-22.

53. Alarcon Aguilara FJ, Roman Ramos R, Perez Gutierrez S, Aguilar Contrerasa, Contreras Weber CC, Flores Saenz JL. Study of antihyperglycemic effects of plants used as antidiabetics. J Ethnopharmacol 1996;61:101-10.

54. Alberto JNS. Antioxidant therapy: myth or reality. J Braz Chem Soc 2005;16:699-710.

55. Marfella R, Quagliaro L, Nappo F, Ceriello A, Giugliano D. Acute hyperglycemia induces an oxidative stress in healthy subjects. J Clin Investigation 2001;108:635-6.

56. Janero DR. Malondialdehyde and thiobarbituric acid-reactivity as diagnostic indices of lipid peroxidation and peroxidative tissue injury. Free Radical Biol Med 1990;9:515-40. 